\title{
Deactivation of Porcine Reproductive and Respiratory Syndrome Virus during Microwave Heating of Bacon
}

\author{
Emily R. Mills', Rhiannon M. Barry², Suzanne E. Myers ${ }^{3}$ and Edward W. Mills ${ }^{1 *}$
}

${ }^{1}$ Department of Animal Science, Penn State University, University Park PA 16802, USA

${ }^{2}$ Department of Entomology, Penn State University, University Park PA 16802, USA

${ }^{3}$ Myers Stables, Port Matilda, PA 16870, USA

\begin{abstract}
Deactivation of Porcine Reproductive and Respiratory Syndrome (PRRS) virus during manufacture and microwave cooking of bacon was investigated. Internal cooking temperatures of bacon were measured and used as a model for evaluating thermal deactivation of virus in growth media and in bacon. Thermal deactivation of virus was assessed in inoculated commercial bacon, in bacon manufactured in the pilot plant following viral inoculation of fresh bellies and in bacon from hogs inoculated with PRRS virus. Internal temperature of $110-136^{\circ} \mathrm{C}$ was observed in bacon cooked using microwave heating. With commercial sliced bacon, up to 6.8 log reduction of viral titer was achieved for bacon heated by microwave to $110^{\circ} \mathrm{C}$ or higher. Bacon manufacturing trials with samples heated by convection to $53^{\circ} \mathrm{C}$ (typical for smoked bacon) produced a 3.1 log reduction of viral titer. Low occurrence of PRRS virus in bellies of infected pigs coupled with greater than 3 and 6 log reductions during bacon manufacture and microwave heating, respectively, lead to high confidence that no active virus remains in microwave cooked bacon. Microwave cooked bacon is safe for import into PRRS-free regions.
\end{abstract}

Keywords: Bacon; Microwave; PRRS virus; Precooked; Pork

\section{Introduction}

Porcine Reproductive and Respiratory Syndrome (PRRS) is one of the most economically important infectious diseases affecting swine, causing reproductive failure in sows as well as pneumonia and wasting in newborn pigs. Transmission of PRRS virus to recipient pigs through consumption of infected donor pig meat has been documented experimentally $[1,2]$ providing the justification for PRRS free countries to exclude import of uncooked or minimally cooked pork products such as bacon.

Bacon is among the highest value-added products produced from pork. Bacon manufacture from pork bellies typically involves several steps. Initially the bellies are injected with a brine curing solution at $10-12 \%$ pump and then smoked and partially cooked to an internal temperature of about $53^{\circ} \mathrm{C}$. The smoked bacon is then air chilled to approximately -3 to $-2^{\circ} \mathrm{C}$, pressed into a uniform shape, sliced and vacuum packaged. Since bacon is only heated to about $53^{\circ} \mathrm{C}$ during manufacture, further cooking is necessary before the product is consumed. Due to the risk of PRRS virus, sliced bacon is generally precluded from import by PRRS-free countries such as Australia and New Zealand.

To provide added convenience for consumers many US meat processors offer "precooked bacon". Precooked bacon is manufactured and sliced as usual then subjected to an additional cooking step to produce fully cooked, ready-to-eat slices. The precooked bacon may be reheated by frying or microwaving or it may be consumed without reheating. It is not known, however, if this process is adequate to destroy PRRS virus that may be present in bacon produced from infected pigs.

Microwave heating is the procedure used by most plants in the preparation of precooked bacon. Bacon is sliced onto a conveyor that moves the slices through one or more microwave chambers until it reaches the desired degree of doneness or crispness. Microwave heating time is typically 1-1.5 minutes. During the heating process fat and water are rendered out of the bacon and water is evaporated. USDA regulations for precooked sliced bacon require that the weight loss during cooking should reach or exceed $60 \%$ of the starting weight [3]. USDA does not specify a final internal temperature for microwave cooked bacon. Measurement of temperature within a microwave oven is technically challenging since most metallic devices such as thermocouples or thermistors are directly affected by the microwave energy. Infrared sensors may be used to assess the surface temperature of bacon during microwave heating, but changing color of the surface during heating is a significant confounding factor. Thus, most bacon processors have decided to forego temperature measurement during heating. Process control endpoints for cooking are bacon color, crispness and USDA mandated cook loss.

PRRS virions are relatively heat labile and sensitive to low $\mathrm{pH}$, lipid solvents, detergents, UV irradiation and many disinfectants [4]. Heating at $56^{\circ} \mathrm{C}$ for $1 \mathrm{~h}$ produced about $3 \log$ reduction in viral titer [5] but no information was found indicating the susceptibility of PRRS virus when rapidly heated for a very short time as during microwave cooking of bacon.

The purpose of this work is to assess the deactivation of PRRS virus subjected to the temperatures and conditions occurring in bacon during manufacture and subsequent microwave heating. The results of this work will allow animal health officials and regulators to decide if microwave cooked bacon should be considered safe for the purpose of importing into countries that are free of PRRS virus.

*Corresponding author: Edward W. Mills, Department of Animal Science, Penn State University, University Park PA 16802, USA, Tel: 814-865-2394; Fax 814-8657442; E-mail: ewm3@psu.edu

Received January 08, 2015; Accepted January 28, 2015; Published January 30 2015

Citation: Mills ER, Barry RM, Myers SE, Mills EW (2015) Deactivation of Porcine Reproductive and Respiratory Syndrome Virus during Microwave Heating of Bacon. J Veterinar Sci Technol 6: 213. doi:10.4172/2157-7579.1000213

Copyright: $\odot 2015$ Mills ER, et al. This is an open-access article distributed under the terms of the Creative Commons Attribution License, which permits unrestricted use, distribution, and reproduction in any medium, provided the original author and source are credited. 


\section{Materials and Methods}

\section{Bacon temperature during microwave heating}

Knowledge of the temperature of bacon during and following microwave heating is integral to the completion of this project. Initial trials were conducted to measure the internal temperature of bacon slices microwave-cooked to desired doneness in approximately 1 minute. Regular sliced, smoked bacon was purchased at retail in 1 pound packages from six different suppliers and two different dates of manufacture. Bacon slices were placed between two paper towels on a microwave-safe plastic tray. Two probes (Model STF-2, Luxtron ${ }^{\circ}$ Fluoroptic Thermometry, Santa Clara, CA) were inserted near the center of the bacon slice; one into lean tissue and the other into fatty tissue. These probes, measuring internal temperature, remained in place throughout cooking and during post-cooking data collection.

The bacon was cooked in a $1.5 \mathrm{KW}$ microwave oven (Model DE6840289B, General Electric) for 1 minute on full power. Bacon slices were then removed from the oven and monitored at room temperature for an additional 30 seconds. Temperature observations were recorded once per second for approximately 100 seconds beginning with the start of the microwave cooking process. Cook loss was calculated using weights recorded before heating and after cooling to room temperature. Two observations were made for each of six brands on each of two days for a total of 24 temperature profiles.

\section{Virus stocks}

A laboratory reference strain of PRRS virus was obtained from the National Veterinary Services Laboratory (NVSL), (Ames, Iowa) and used in some experiments. Other experiments were conducted using Ingelvac ${ }^{\bullet}$ PRRS MLV, an inactivated vaccine strain of PRRS obtained from Boehringer Ingelheim. Both viruses were propagated in MA104 cells maintained in Dulbecco's Modified Eagle's Medium (DMEM) supplemented with $10 \%$ fetal bovine serum, L-glutamine, sodium pyruvate, non-essential amino acids, antibiotics and antimycotics. Cells were plated 3 days prior to inoculation with virus and cultured in a $5 \% \mathrm{CO}_{2}$-air atmosphere at $37^{\circ} \mathrm{C}$ for 5 days prior to harvesting virus. Clarified cell culture supernatant containing virus was prepared by centrifugation at $9000 \mathrm{rpm}$ for 10 minutes at room temperature following one freeze-thaw cycle and used as inoculum in future experiments. Viral stocks were stored at $-80^{\circ} \mathrm{C}$ in $2 \mathrm{ml}$ aliquots containing 5\% dimethylsulfoxide (DMSO) until needed for testing. Prior to use viral stocks were quick thawed in a $37^{\circ} \mathrm{C}$ water bath and used for experimentation within 1 hour of thawing.

\section{Virus titration by TCID}

Stock virus and virus from experimental studies were titered by TCID $_{50}$ on 72-hour MA-104 cells in 96-well tissue culture plates. Bacon or tissue samples were homogenized in $6 \mathrm{ml}$ of viral transport media (DMEM supplemented with sodium pyruvate, L-glutamine, antibiotics and antimycotics) and the lysate clarified by centrifugation (10 minutes; $4000 \mathrm{xg}$ ). Ten fold serial dilutions of virus stocks or samples were prepared in DMEM without fetal bovine serum and $100 \mathrm{ul}$ added to each of 12 wells per dilution. Cells were incubated for 1 hour at $37^{\circ} \mathrm{C}$ with viral inoculum after which time the inoculum was removed and cells were washed and covered with supplemented DMEM. Cells were incubated for an additional 5 days at $37^{\circ} \mathrm{C}$ after which time viral cytopathic effects were observed and recorded. Each titration included negative (media only) and positive control (Ingelvac ${ }^{\bullet}$ PRRS MLV) wells. Calculation of TCID $_{50}$ was performed by the method of Reed and Muench [6].

\section{Thermal destruction of PRRSV during microwave heating}

Thermal destruction of PRRS virus was assessed under four experimental conditions: 1. Rapid microwave heating of virus in growth media, 2. Rapid microwave heating of virus inoculated onto commercial sliced bacon, 3 . Slow $(3 \mathrm{~h})$ convection heating with virus inoculated onto fresh pork then subjected to typical bacon curing and cooking procedures, and 4 . Fresh pork from pigs infected with virus subjected to typical bacon curing and cooking procedures.

In the first experiment $\left(4.48 \log \mathrm{TCID}_{50}\right)$ NVSL virus stock was used. One $\mathrm{ml}$ of virus stock along with $2 \mathrm{ml}$ of growth media were heated in a closed $10 \mathrm{ml}$ glass tube. Temperature was measured using a flouroptic probe (Model STF-2, Luxtron ${ }^{\circ}$ Fluoroptic Thermometry, Santa Clara, CA) taped to the surface of the tube and enclosed in glass wool insulation. Each sample was heated by microwave (Model DE6840289B, General Electric, $1.5 \mathrm{KW}$ ) for about $60 \mathrm{sec}$. Peak temperature was recorded shortly after the microwave power was turned off. After heating, viral titer was determined as described above. Nine observations were made with peak temperatures ranging from 66 to $111.2^{\circ} \mathrm{C}$

In the second experiment (4.48 log $\mathrm{TCID}_{50}$ ) NVSL virus stock and $\left(\log 7.28\right.$ TCID $\left._{50}\right)$ Ingelvac ${ }^{\oplus}$ virus stock were used along with commercial sliced bacon from three different manufacturers. Bacon was purchased from local retail stores on the day of testing and refrigerated until used. One $\mathrm{ml}$ of virus stock along with $1 \mathrm{~g}$ of diced bacon and $1 \mathrm{ml}$ of growth media were heated in a closed $10 \mathrm{ml}$ glass tube. Temperature was measured using a flouroptic probe (Luxtron, model STF-2, Santa Clara, CA) taped to the surface of the tube and enclosed in glass wool insulation. Each sample was heated by microwave (Model DE6840289B, General Electric, $1.5 \mathrm{KW}$ ) for about $60 \mathrm{sec}$. Peak temperature was recorded shortly after the microwave power was turned off. After heating, the sample was cooled to room temperature and viral titer was determined as described above. Twenty five observations were made with peak temperatures ranging from 52.3 to $136.0^{\circ} \mathrm{C}$.

In the third experiment the destruction of PRRS virus was evaluated in a model system mimicking the manufacture of bacon. Fresh pork belly sections $\left(5 \mathrm{~cm}^{2}\right)$ were cured by hand injection (12\% pump) of a curing brine comprised of salt (18.4\%), sugar (4\%), sodium phosphate (4\%), sodium nitrite $(0.094 \%)$, sodium erythorbate $(0.5 \%)$, and water (73\%). After injection the belly section was drenched in Red Arrow Charsol Cherrywood Poly 2515 liquid smoke (Product \# 2515-005, Red Arrow Products, Manitowoc, WI) at 5\% concentration for 2 minutes. Equal portions (wt:vol) of cured belly and virus stock $\left(6.2 \log\right.$ TCID $\left._{50}\right)$ were combined and heated in a programmable oven (Hewlett Packard Model 5890, Avondale, IL) following a temperature program derived from a commercial bacon smokehouse (Kerres Model Jet Smoke Maxi 3001 LCD, Backnang, Germany). In short, the temperature of the bacon with virus stock was raised from ca. 10 to $53^{\circ} \mathrm{C}$ (typical final temperature for smoked bacon) in 3 hours.

In the fourth experiment fresh belly sections from 5 virusinoculated hogs were subjected to bacon manufacture (curing and cooking as described above for experiment 3) followed by microwave heating. Viral titers were determined for raw belly, cured bacon and after microwave heating of the bacon.

\section{Inoculation of hogs with PRRS virus}

Five Yorkshire hogs (two barrows and three gilts weighing about $90-95 \mathrm{~kg}$ each) were inoculated by intranasal atomization of $0.75 \mathrm{~mL}$ of $4 \log$ TCID $_{50}$ of NVSL PRRS virus into each nostril. 
Hogs were housed in a common pen with one feeder and one water nipple and observed daily for overt clinical signs of PRRS infection including lethargy, increased respiratory distress and elevated body temperatures (rectal temperature). Two hogs had elevated body temperature or demonstrated lethargy at seven days post inoculation and were euthanized for sampling. The remaining three hogs were euthanized at the termination of the trial 14 days post inoculation at which time slightly elevated body temperatures were observed. Hogs were euthanized after being restrained and stunned using a captive bolt stunner following accepted humane slaughter procedures. Blood samples were collected during exsanguination and samples of mesentery lymph node, spleen, lung and belly were excised for virus titration by TCID $_{50}$ or PCR analysis. Belly sections were divided into 5 $\mathrm{cm}^{2}$ sections for bacon manufacture as described above. Samples were frozen at $-80^{\circ} \mathrm{C}$ until used for analyses. All animal handling, care and euthanasia were conducted in accordance with The Pennsylvania State University's Institutional Animal Care and Use Committee guidelines (protocol number PSU23196).

\section{Real-time reverse transcriptase polymerase chain reaction (RT-PCR)}

Pig tissues were analyzed for PRRS virus RNA by real-time RTPCR. Samples of lung, spleen, mesenteric lymph node, belly (2 different sites) and serum were homogenized in Trizol (Invitrogen, Carlsbad, CA) followed by chloroform extraction of total RNA. RNA was reverse transcribed and cDNA amplified in a single step reaction using the Super Script III Platinum One Step qRT-PCR kit (Invitrogen; No. 11732-020, Carlsbad, CA) and primers and probe specific for a114 bp region of the nucleocapsid gene at the 3' end of ORF7 and the 3' UTR. The sequences for the primers and probe are listed in Table 1 . The reaction was performed by heating initially to $50^{\circ} \mathrm{C}$ for 30 minutes and denaturing of the reverse transcriptase enzyme at $95^{\circ} \mathrm{C}$ for 13 minutes. This was followed by 45 cycles of $94^{\circ} \mathrm{C}$ for 15 seconds and $60^{\circ} \mathrm{C}$ for 1 minute for cDNA amplification. Results were analyzed using iCycler IQ software. The real time RT-PCR standard curve showed a $95.9 \%$ efficiency and $\mathrm{R}^{2}=99.8 \%$.

\section{Statistical analysis}

Temperature and thermal deactivation data were recorded in Excel spreadsheets where mean, variance and regression computations were completed. Log reductions of viral titer in samples were calculated by subtracting the viral titer $\left(\mathrm{TCID}_{50}\right)$ after treatment from the initial viral titer.

\section{Results and Discussion}

Thermal destruction of PRRS virus was evaluated using heating conditions modeled to match those observed during manufacture of bacon and in the microwave heating process used in preparation of ready-to-eat bacon. In order to model the microwave cooking process internal temperature of sliced bacon was measured using fluoroptic temperature probes during microwave heating. The internal temperatures of regular sliced bacon lean and fat rose to $137^{\circ} \mathrm{C} \pm$ 7.1 and $134^{\circ} \mathrm{C} \pm 6.6$ respectively during approximately 1 minute of microwave heating. The temperature of the lean rose more rapidly until about $100^{\circ} \mathrm{C}$ then slowed briefly, possibly due to evaporative cooling with product losing more than $66 \%$ of its weight through drip and evaporation. Peak temperatures were recorded about 3 seconds after the microwave oven was turned off, indicating a slight lag in the temperature recording system. The hot bacon slices were removed from the oven to a room temperature environment where they cooled to less than $90^{\circ} \mathrm{C}$ in about 30 seconds. In the course of 24 bacon heating trials which exceeded the $60 \%$ cook loss required by USDA [3] the lowest observed average (lean + fat) peak slice temperature was $110.6^{\circ} \mathrm{C}$ Bacon heated to this temperature did not exhibit typical cooked bacon color or crispness. In a commercial manufacturing plant such product would likely be heated to a higher temperature to achieve the desired color and crispness. Thus, it is reasonable to assume that commercial, microwave cooked bacon is typically heated to greater than $110^{\circ} \mathrm{C}$.

For virus stock heated in growth media at temperatures up to $111.2^{\circ} \mathrm{C}$, trials show complete destruction of the virus ( $4.0 \mathrm{log}$ reduction) when subjected to temperatures above $70^{\circ} \mathrm{C}$ (Figure 1). Titers in the diluted supernatant media for these trials were not greater than $4.0 \mathrm{log}$, so this is the maximum log reduction that could be demonstrated.

When commercial bacon was inoculated with virus and heated, the thermal deactivation of the PRRS virus increased with temperatures up to about $110^{\circ} \mathrm{C}$. Above $110^{\circ} \mathrm{C}$ no virus was detected using the virus isolation method. These trials were initially conducted using a virus stock with diluted viral titer of $4.0 \log$ (Figure 2), and later, with diluted viral titer of $6.8 \log$ (Figure 3). Complete thermal destruction of the virus was achieved in fourteen trials, ten at the $6.8 \mathrm{log}$ titer and four at $4.0 \mathrm{log}$ titer. If one considers only those observations with peak temperatures below $110^{\circ} \mathrm{C}$ (above $110^{\circ} \mathrm{C}$ there was no virus detected), linear regression gives a $\mathrm{Z}$ value of $12^{\circ} \mathrm{C}$ per 1 log reduction. These findings are consistent with the principle that thermal destruction is a function of both temperature and time of exposure. Other researchers Benfield et al. [5] and Bloemraad et al. [7] have reported thermal destruction of the PRRS virus after $1 \mathrm{hr}$ at $56^{\circ} \mathrm{C}$. However, there are no other reports indicating the temperature needed for thermal destruction of PRRS virus when the heating time is only one minute as for microwave cooked bacon.

In the third trial a model bacon manufacturing process was established including brine injection followed by a three hour heating

\begin{tabular}{|c|c|c|}
\hline Primer & Sequence & Base Position \\
\hline F1 & 5' ATG ATG RGC TGG CAT TCT 3' & $(15,257-15,274)$ \\
\hline F2 & 5' ATR ATG RGC TGG CAT TCC 3' & \\
\hline F3 & 5' ATG ATG GGC CGG CGT TCC 3' & \\
\hline R1 & 5' ACA CGG TCG CCC TAA TTG 3' & $(15,353-15,370)$ \\
\hline Probe & $\begin{array}{c}\text { 5'HEX-TGT GGT GAA TGG CAC TGA TTG ACA- } \\
\text { BHQ2 3' }\end{array}$ & $(15,307-15,330)$ \\
\hline
\end{tabular}

Table 1: Primer and probe sequences for the North American strain VR-2332 of PRRSV used to detect viral RNA in tissue samples from infected hogs.

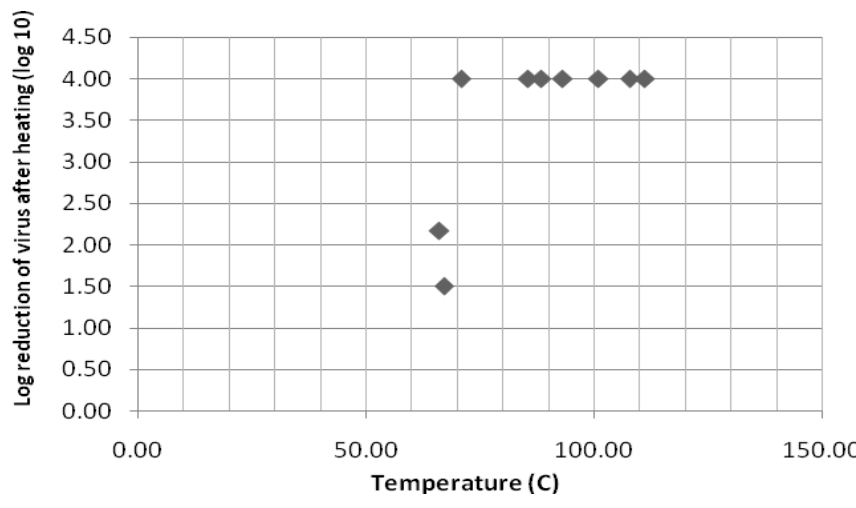

Figure 1: Peak temperature after microwave heating for 1 minute affects destruction of porcine reproductive and respiratory syndrome virus in liquid media (4.0 log $\mathrm{TCID}_{50}$, NVSL virus). 
Citation: Mills ER, Barry RM, Myers SE, Mills EW (2015) Deactivation of Porcine Reproductive and Respiratory Syndrome Virus during Microwave Heating of Bacon. J Veterinar Sci Technol 6: 213. doi:10.4172/2157-7579.1000213

Page 4 of 5

step during which the sample temperature was slowly raised to $53^{\circ} \mathrm{C}$. In these tests, the titer of the diluted virus stock was $6.2 \log$ (Table 2). When sampled for viral titer the freshly manufactured bacon produced some minor cytopathic effects in the MA-104 cells, probably due to the salt, sodium nitrite or other curing ingredients. This confounding effect was limited to wells with undiluted sample and was not observed at $10^{-1}$ or greater dilutions. Undiluted sample wells were not used in the $\mathrm{TCID}_{50}$ calculations since titers were $3 \log$ or higher. The final titer

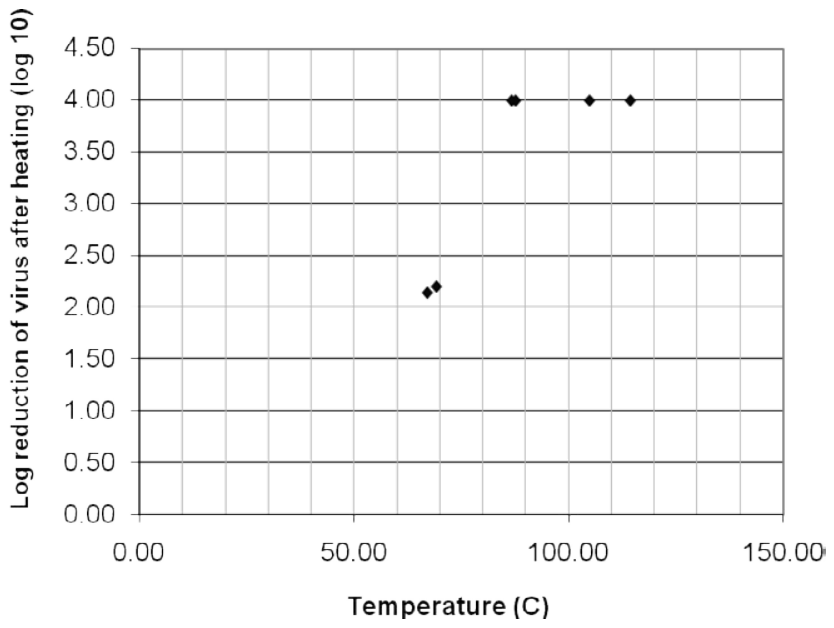

Figure 2: Peak temperature after microwave heating for 1 minute affects destruction of porcine reproductive and respiratory syndrome virus in inoculated bacon (4.0 log $\mathrm{TCID}_{50}$, NVSL virus).

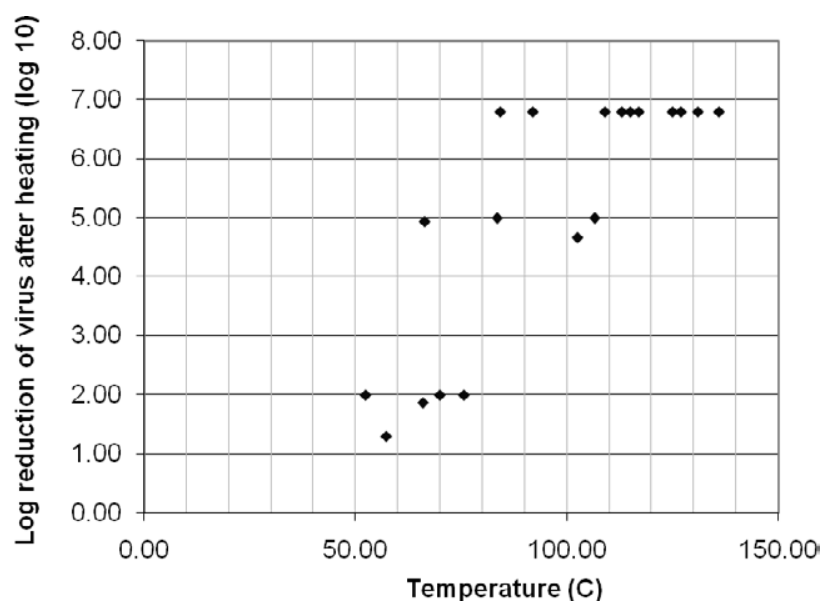

Figure 3: Peak temperature after microwave heating for 1 minute affects destruction of porcine reproductive and respiratory syndrome virus in inoculated bacon (6.8 log $\mathrm{TCID}_{50}$, Engelvac virus).

\begin{tabular}{|c|c|c|}
\hline Treatment & Viral Titre $^{a}$ & Log Reduction \\
\hline Virus stock & $6.20 \pm 0.49$ & \\
\hline Virus stock heated ${ }^{\mathrm{b}}$ & $2.79 \pm 0.22$ & 3.4 \\
\hline Cured belly with virus stock heated ${ }^{\mathrm{b}}$ & $3.08 \pm 0.28$ & 3.1 \\
\hline
\end{tabular}

a Log TCID50 \pm standard deviation.

bSamples were heated to $53^{\circ} \mathrm{C}$ during 3 hours in a convection oven to model typical thermal processing of smoked bacon.

Table 2: Thermal deactivation of porcine reproductive and respiratory syndrome virus during bacon manufacture.

\begin{tabular}{|c|c|c|}
\hline Tissue & Viral titre & PCR result $\left(\right.$ ratio positive ${ }^{\mathrm{c}}$ ) \\
\hline Serum & nd $^{\mathrm{d}}$ & $5 / 5$ \\
\hline Lung & nd & $5 / 5$ \\
\hline Mesentery lymph node & nd & $3 / 4$ \\
\hline Spleen & nd & $5 / 5$ \\
\hline Belly-flank end & nd & $2 / 4$ \\
\hline Belly-shoulder end & nd & $5 / 5$ \\
\hline
\end{tabular}

aTissues collected at necropsy within one hour after death.

${ }^{\text {b}}$ Five pigs $(90-95 \mathrm{~kg})$ inoculated by intranasal atomization with $0.75 \mathrm{ml}$ of virus stock (4 log NVSL TCID ${ }_{50}$ ) into each nostril.

'Ratio of PRRS positive samples to total completed tests.

dNone detected using virus isolation technique.

Table 3: Porcine reproductive and respiratory syndrome virus in tissues ${ }^{a}$ of inoculated ${ }^{\mathrm{b}}$ pigs.

following the bacon manufacturing process was $3.08 \mathrm{log}$, indicating a $3.12 \log$ reduction due to the bacon manufacturing process. This is similar to the 3- $4 \log$ reductions reported by Benfield et al. [5] and Bloemraad et al. [7] following $1 \mathrm{~h}$ at $56^{\circ} \mathrm{C}$.

In the final trial, hogs from a PRRS-free herd were inoculated with PRRS virus and allowed to develop infection for 1-2 weeks before harvesting. Presence of PRRS viral nucleic acid was confirmed by positive RT-PCR results in serum, lung, mesentery, lymph node, spleen and belly of each hog (Table 3). However, virus isolation was unable to detect virus in any of those samples. Virus isolation was also unable to detect virus in bacon manufactured from bellies of PRRSinfected pigs. This is in agreement with the work of Larochelle and Magar [8] who reported that RT-PCR detected viral nucleicsxa acid at concentrations as low as 0.355 infectious virions per ml. Virus isolation procedures require at least 1 infectious virion per $\mathrm{ml}$ in order to give a positive result. Like the current project, various reports Magar et al. [2], Larochelle and Magar [8] and Magar and Larochelle [9] have shown low but detectable levels of PRRS virus in raw meat products from PRRS-infected pigs.

\section{Conclusions}

Microwave cooking of bacon to required cook-loss and crispness endpoints leads to internal product temperatures well in excess of $110^{\circ} \mathrm{C}$. Even though the time is short (one minute), microwave cooking of bacon produces greater than $6 \mathrm{log}$ reduction in PRRS viral titer when peak temperature is at least $110^{\circ} \mathrm{C}$. No PRRS virus was detected by viral titer technique in microwave precooked bacon manufactured from bellies of PRRS infected pigs. The low occurrence of PRRS virus in raw pork bellies and the greater than $6 \log$ reduction during cooking combine to assure that no detectable virus remains in microwave cooked bacon.

\section{Acknowledgements}

Work sponsored in part by The American Pork Export Trading Company, in cooperation with the National Pork Producers Council.

\section{References}

1. Van der Linden IFA, Van der Linde-Bril EM, Voermans JJM, Van Rijn PA, Po JMA, et al. (2003) Oral transmission of porcine reproductive and respiratory syndrome virus by muscle of experimentally infected pigs. Vet Microbiol 97 45-54.

2. Magar R, Robinson Y, Dubuc C, Larochelle R (1995) Evaluation of the persistence of porcine reproductive and respiratory syndrome virus in pig carcasses. Vet Rec 137: 559-561.

3. USDA, FSIS OPPED (2005) Food Standards and Labeling Policy Book.

4. Murphy FA, Gibbs EPJ, Horzinek MC, Studdert MJ (1999) Arteriviridae. In: Veterinary Virology Third Edition . Academic Press, San Diego CA, pp. 509515 
Citation: Mills ER, Barry RM, Myers SE, Mills EW (2015) Deactivation of Porcine Reproductive and Respiratory Syndrome Virus during Microwave Heating of Bacon. J Veterinar Sci Technol 6: 213. doi:10.4172/2157-7579.1000213

5. Benfield DA, Nelson E, Collins JE, Harris L, Goyal, et al. (1992) Characterization of swine infertility and respiratory syndrome (SIRS) virus (isolate ATCC VR2332). J Vet Diagn Invest 4: 127-133.

6. Reed LJ, Muench H (1938) A simple method of estimating 50 percent end points. Amer. Jour. Hygiene 27: 493-497.

7. Bloemraad M, de Kluijver EP, Petersen A, Burkhardt GE, Wensvoort G (1994) Porcine reproductive and respiratory syndrome: temperature and $\mathrm{pH}$ stability of Lelystad virus and its survival in tissue specimens from viraemic pigs. Vet Microbiol 42: 361-371.
8. Larochelle R, Magar R (1997) Evaluation of the presence of porcine reproductive and respiratory syndrome virus in packaged pig meat using virus isolation and polymerase chain reaction (PCR) method. Vet Microbiol 58: 1-8.

9. Magar R, Larochelle R (2004) Evaluation of presence of porcine reproductive and respiratory syndrome virus in pig meat and experimental transmission following oral exposure. Can J Vet Res 68: 259-266. 